\title{
Total Phenol Content and Gastric Anti-Ulcer Activity of Hydroalcoholic Extract of Persea caerulea (Ruiz \& Pav.) Mez. Bark
}

\author{
Abhel A. Calderón-Peñaa,*, Cinthya L. Aspajo-Villalaz', Carmen R. Silva-Correa ${ }^{2}$, Víctor E. Villarreal-La Torre ${ }^{2}$, \\ María V. González-Blas², Orlando E. Pretel-Sevillano', Marco L. Salazar-Castillo', Maricielo Vaella-Alarcón', \\ Franco Huaccha-Cáceres ${ }^{1}$, Jonatam León-Soto ${ }^{1}$, Whendy Alaya-Davirán' ${ }^{1}$, Anabel D. González-Siccha ${ }^{2}$, William \\ Antonio Sagástegui-Guarniz², Luz M. Guerrero-Espino ${ }^{3}$, Julio Hilario-Vargas ${ }^{3}$
}

Abhel A. Calderón-Peña ${ }^{1, *}$, Cinthya L. Aspajo-Villalaz ${ }^{1}$, Carmen R. Silva-Correa ${ }^{2}$, Víctor

E. Villarreal-La Torre², María V. González-Blas², Orlando E. Pretel-Sevillano', Marco L. Salazar-Castillo ${ }^{1}$, Maricielo Vaella-Alarcón', Franco HuacchaCáceres', Jonatam León-Soto', Whendy Alaya-Davirán ${ }^{1}$, Anabel D. González-Siccha ${ }^{2}$, William Antonio Sagástegui-Guarniz², Luz M. Guerrero-Espino ${ }^{3}$, Julio Hilario-Vargas ${ }^{3}$

'Facultad de Ciencias Biológicas, Universidad Nacional de Trujillo, PERÚ.

${ }^{2}$ Facultad de Farmacia y Bioquímica, Universidad Nacional de Trujillo, PERÚ.

${ }^{3}$ Facultad de Medicina, Universidad Nacional de Trujillo, PERÚ.

\section{Correspondence}

\section{Abhel A. Calderón-Peña}

Facultad de Ciencias Biológicas,

Universidad Nacional de Trujillo, PERÚ.

E-mail: acalderonp@unitru.edu.pe

History

- Submission Date: 05-05-2021;

- Review completed: 18-06-2021;

- Accepted Date: 23-06-2021.

DOI : 10.5530/pj.2021.13.139

Article Available online http://www.phcogj.com/v13/i5

Copyright

(C) 2021 Phcogj.Com. This is an openaccess article distributed under the terms of the Creative Commons Attribution 4.0 International license.

\section{ABSTRACT}

Objective: Determine the content of total phenols and evaluate the gastroprotective effect of the extract of Persea caerulea (Ruiz \& Pav.) Mez. in mice with induced gastric ulcer. Material and Methods: The bark of Persea caerulea was macerated in $70 \%$ ethanol and the phenol content was determined using the Folin-Ciocalteu method. The female Mus musculus Balb/c specimens were distributed in the following groups: White Control Group, without indomethacin dosing; Negative Control Group, dosing with indomethacin; Positive Control Group treated with ranitidine at a dose of $50 \mathrm{mg} / \mathrm{kg}$; Groups $P$. caerulea treated with extract at doses of $50 \mathrm{mg} / \mathrm{kg}, 100 \mathrm{mg} / \mathrm{kg}$ and $200 \mathrm{mg} / \mathrm{kg}$. Gastric ulcer was induced with indomethacin orally at a dose of $50 \mathrm{mg} / \mathrm{kg}$, the procedure was repeated 12 hours later; Gastroprotective treatment was administered 60 minutes after each dose of indomethacin, 6 hours after the last dose, sodium pentobarbital was euthanized and the stomach was resected to determine ulceration using the Marhuenda Scale. Results: Higher percentages of gastric ulcer inhibition were obtained in the $P$. caerulea $100 \mathrm{mg} / \mathrm{kg}(80 \%)$ and P. caerulea $200 \mathrm{mg} / \mathrm{kg}(85.71 \%)$ groups. Conclusions: Extract of Persea caerulea (Ruiz \& Pav.) Mez., At doses of 100 and $200 \mathrm{mg} / \mathrm{kg}$ of body weight, has a gastric antiulcerative effect which is related to its content of total polyphenols.

Key words: Gastric Ulcer, Mice, Indomethacin

\section{INTRODUCTION}

Gastric ulcer is a common disease of the digestive system $^{1}$, caused by stomach acids that damage its lining, causing pain, and sometimes bleeding. Peptic ulcer (gastric or duodenal) is the cause of dyspepsia in approximately $10 \%$ of people. ${ }^{2}$ Current therapeutic treatments are highly dependent on Western medicine; however, numerous studies have shown that medicinal plants can effectively treat gastric ulcer in many animal models, through different mechanisms, which include stimulation of the proliferation of mucous cells, inhibition of secretion of gastric acid and $\mathrm{H}^{+} / \mathrm{K}^{+}$ATPase activity, activity, and antimicrobial properties. ${ }^{1}$

Use of medicinal plants plays a fundamental role in disease prevention. ${ }^{3}$ Medicinal plant-based drugs are considered as alternatives for treatment, since they have fewer or no side effects, compared to the appearance of many side effects from the use of synthetic drugs. ${ }^{4-5}$

Persea caerulea (Ruiz \& Pav.) Mez (P. caerulea) is a plant belonging to the Lauraceae family and grows between 350 and 2200 meters above sea level (MASL). ${ }^{6}$ Studies determined the presence of metabolites such as kaempferol-3$\mathrm{O}-\alpha$-L-rhamnopyranoside, quercetin-3-O- $\alpha$-Lrhamnopyranoside, quercetin-3-O- $\beta$-glucoside, and scopoletin ${ }^{7}$; Coumarins and flavonoids, isofraxidine, campesterol, stigmasterol and $\beta$-sitosterol were also found. ${ }^{8}$

\section{MATERIAL AND METHODS}

\section{Vegetal material}

The barks of Persea caerulea (Ruiz \& Pav.) Mez were collected in San Martín Region, Perú.

\section{Experimental animals}

Thirty female Mus musculus Balb/c mice, 12 to 14 weeks old and weighing between 30 to $35 \mathrm{~g}$, were used and received balanced food and water ad libitum. All procedures were approved by the Ethics Committee of the School of Medicine, Universidad Nacional de Trujillo for the care and use of animals (COD document. $\mathrm{N}^{\circ} 002$ - 2020)

Preparation of the hydroalcoholic extract

Barks were washed repeatedly with distilled water, then it was completely dried in a stove at $45^{\circ} \mathrm{C}$. Barks dried were ground in a manual mill until obtaining a fine powder. $50 \mathrm{~g}$ of this fine powder were macerated in $500 \mathrm{~mL}$ of $70 \%$ ethanol in amber hermetic sealed flasks with stirring for $5 \mathrm{~min}$ daily for 7 days. Subsequently, it was vacuum filtered with filter paper and put in porcelain capsules for drying up in stove at $45{ }^{\circ} \mathrm{C}$; dry extract was kept in amber bottle in refrigeration $\left(2\right.$ to $\left.4{ }^{\circ} \mathrm{C}\right)$ until it was used..$^{9}$

\section{Determination of total phenol content}

It was determined with the Folin-Ciocalteu reagent. A calibration curve with gallic acid as a standard was obtained, It was prepared by adding 2 milligrams of 
Gallic acid in $10 \mathrm{ml}$ of methanol as stock solution, concentrations of $100,50,25$ and $12.5 \mu \mathrm{g} / \mathrm{ml}$ were prepared. Then $0.5 \mathrm{~mL}$ of each standard and extract were mixed with $2.5 \mathrm{~mL}$ of Folin-Ciocalteu $50 \%$ and 2.5 $\mathrm{mL}$ of distilled water, and incubated for $5 \mathrm{~min}$ at $40^{\circ} \mathrm{C}$. Finally, $2 \mathrm{~mL}$ of $\mathrm{Na}_{2} \mathrm{CO}_{3}$ solution was added $(7.5 \%$, w/v). The final mixture was shaken and incubated for $15 \mathrm{~min}$ at $40^{\circ} \mathrm{C}$. The absorbance of all standards and samples was measured at $765 \mathrm{~nm}$ using a UV-Vis spectrophotometer. The results were expressed as $\mathrm{mg}$ Gallic acid equivalents (GAE)/g extract. ${ }^{10}$

\section{Evaluation of gastric antiulcer activity}

The mice were divided into 6 groups of 5 mice each one. Blank Control Group: 5 days of $0.5 \mathrm{~mL}$ p.o. of physiological saline solution (PSS); 24 hours of fasting: 1st induction with $0.5 \mathrm{~mL}$ of PSS $+0.5 \mathrm{~mL}$ of PSS; 12 hours later: $2 \mathrm{nd}$ induction with $0.5 \mathrm{~mL}$ of PSS $+0.5 \mathrm{~mL}$ of PSS. Negative Control Group: 5 days of PSS ( $0.5 \mathrm{~mL}$ p.o.); 24 hours of fasting: $1 \mathrm{st}$ induction with indomethacin $50 \mathrm{mg} / \mathrm{kg}$ p.o. $+0.5 \mathrm{~mL}$ of SSF; 12 hours later: 2 nd induction with indomethacin $50 \mathrm{mg} / \mathrm{kg}$ p.o. $+0.5 \mathrm{~mL}$ of PSS. Positive Control Group: 5 days of ranitidine $50 \mathrm{mg} / \mathrm{kg}$ p.o.; 24 hours of fasting: 1st induction with indomethacin $50 \mathrm{mg} / \mathrm{kg}$ p.o. + ranitidine 50 mg/kg p. o.; 12 hours later: 2nd induction with indomethacin $50 \mathrm{mg} /$ $\mathrm{kg}$ p.o. + ranitidine $50 \mathrm{mg} / \mathrm{kg}$ p.o. Groups P. caerulea $50 \mathrm{mg} / \mathrm{Kg}, 100$ $\mathrm{mg} / \mathrm{Kg}$ and $200 \mathrm{mg} / \mathrm{kg}$ p.o.: 5 days of extract; 24 hours of fasting: $1 \mathrm{st}$ induction with indomethacin $50 \mathrm{mg} / \mathrm{kg}$ p.o. + extract; 12 hours later: 2nd induction with indomethacin $50 \mathrm{mg} / \mathrm{kg}$ p.o. + extract.

For five consecutive days, gastroprotective treatments were administered to the mice, then they were fasted for 24 hours; After this time, the first induction of ulceration was carried out with $50 \mathrm{mg} / \mathrm{Kg}$ of indomethacin; 12 hours later the first gastric ulcer induction, the second dose of indomethacin $(50 \mathrm{mg} / \mathrm{Kg})$ was administered; 60 minutes after indomethacin administration, the gastroprotective substance ${ }^{11-12}$ was administered. After 6 hours of this last dosage, euthanasia was carried out with a dose of $60 \mathrm{mg} / \mathrm{kg}$ i.p. of sodium pentobarbital to each experimental animal, following the animal bioethics standards ${ }^{13-15}$, after this step, a laparotomy was performed to extirpate the stomach; The extirpated stomach was cut through the greater curvature; then it was extended and PSS was added to make observations.

\section{Determination of the ulceration index and percentage of ulceration inhibition}

Marhuenda Scale was used to determine Ulceration Index, considering the magnitude of the lesion observed in the gastric mucosa (loss of continuity or rupture of the same), for which a vernier caliper was used to measure the length of the ulcerative wounds. Furthermore, the number of ulcers and the presence or absence of bleeding were counted. ${ }^{16}$

Percentage of ulceration inhibition of each experimental animal was calculated, with respect to the ulceration index of the positive control group, as follows:

$\%$ inhibición $=\frac{I . U . G C P-I . U \cdot P .}{I . U . G C P} \times 100$

U.I.CPG $=$ mean ulceration index of positive control group

I.U.P = ulceration index of the problem group, per experimental animal

The mean values of the inhibition percentages of each working group, as well as their standard deviation, were determined.

\section{RESULTS}

\section{Determination of total phenol content}

The amount of total phenols of the hydroalcoholic extract of the bark of $P$ c caerulea was determined by the Folin-Ciocalteu method and 315.11 $\pm 0.97 \mathrm{mg}$ were found expressed as Gallic acid equivalents (GAE) per gram of dry extract. The determination was made in triplicate.

\section{Macroscopic observation of stomachs}

Results of macroscopic study present differences in degrees of ulcerative gastric lesion. Negative Control Group present a large number of ulcerations and petechiae unlike the Positive Control Group that received Ranitidine drug, only small petechiae were observed. While the $P$. caerulea Groups shows a lower number of gastric ulcerations and petechiae, this effect being dose dependent. The ulceration index and the percentage of ulceration inhibition were calculated using the Marhuenda Scale.

\section{Percent inhibition of ulceration}

Results of the observational analysis applying the Marhuenda Scale, allows obtaining the ulceration index, which is finally expressed as a percentage of ulceration inhibition.

\section{DISCUSSION}

The Negative Control Group shows the effect generated by the induction of gastric ulcer with indomethacin when ulcers and bleeding are observed in the gastric mucosa compared to the normal structure of a stomach of the White Control Group (Fig. 1). NSAIDs can cause gastric damage by inhibiting cyclooxygenase (COX) and reducing prostaglandin production. ${ }^{17} \mathrm{COX}$ is the key enzyme for translating arachidonic acid into PG, which includes at least 2 isomerases: COX-1 and COX-2; COX-1 is primarily involved in maintaining the integrity of the gastric mucosa and regulating gastric acid secretion and blood flow, while COX-2 is involved in the repair process of damaged mucosa by promoting PG production in the inflammatory response. ${ }^{18-20}$ Prostaglandin E2 (PGE2) is one of the main metabolites of arachidonic acid, it is well recognized as a protective cellular factor to repair damaged gastric mucosa by inhibiting gastric acid secretion, increasing blood flow in gastric mucosa and promoting protein synthesis and cell renewal. ${ }^{21}$

In addition, Epidermal Growth Factor (EGF) induces the JAK/STAT signaling pathway and the phosphatidylinositol pathway, which is related to immunity and proliferation, which is why a notable reduction in EGF concentration has been reported in gastric ulcers in a large sample of patients. ${ }^{22-23}$ Indomethacin induces gastric mucosa damage in several mechanisms ${ }^{24}$, but activation of $\mathrm{p} 38$ MAPK is one of the most important factors in activating endoplasmic reticulum stress and further damage. ${ }^{25}$ In vitro experiments demonstrate that p38 MAPK and JNK are involved in the loss of barrier function induced by indomethacin in gastric cell line, and this barrier loss occurs through the loss of the barrier protein occludin from the junctions narrow. The protective effect of the inhibition of p38 MAPK on the tight binding protein occludin and, therefore, on the mucosal barrier, was further demonstrated in ex vivo studies using gastric mucosa in murine models. ${ }^{26-27}$

Administration of Ranitidine prevented damage to a high degree of the gastric mucosa (Figure 1). Ranitidine is a very common histamine $\mathrm{H} 2$ receptor antagonist and has a more prominent effect on basal acid secretion and a less profound effect on acid production. ${ }^{28}$ While the experimental animals treated with extract of $P$. caerulea showed a higher percentage of inhibition of ulceration compared to Negative Control group, observing a reduction in gastric damage produced by the administration of indomethacin, in addition, doses of 100 and 200 $\mathrm{mg} / \mathrm{kg}$ of P. caerulea showed a similar effect to Ranitidine (Figure 2).

The tissue damage observed in the gastric mucosa is associated with the intense generation of free radicals such as reactive oxygen species that cause oxidative stress and the consequent damage to the mucosa; These free radicals also alter the function of the cellular antioxidant enzyme 


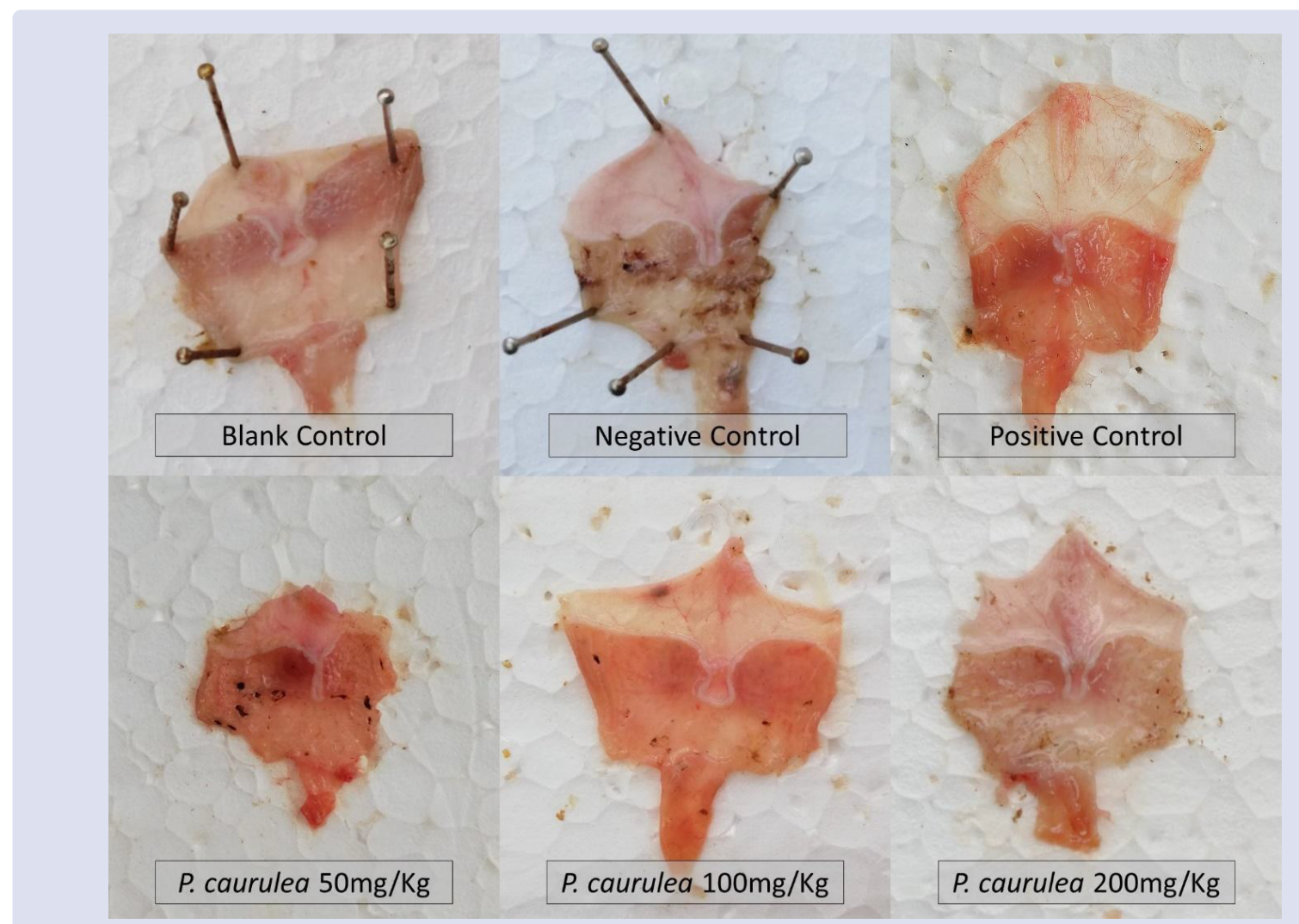

Figure 1: Macroscopic observation of the effect of Persea caerulea (Ruiz \& Pav.) Mez on induced gastric ulcer in mice.

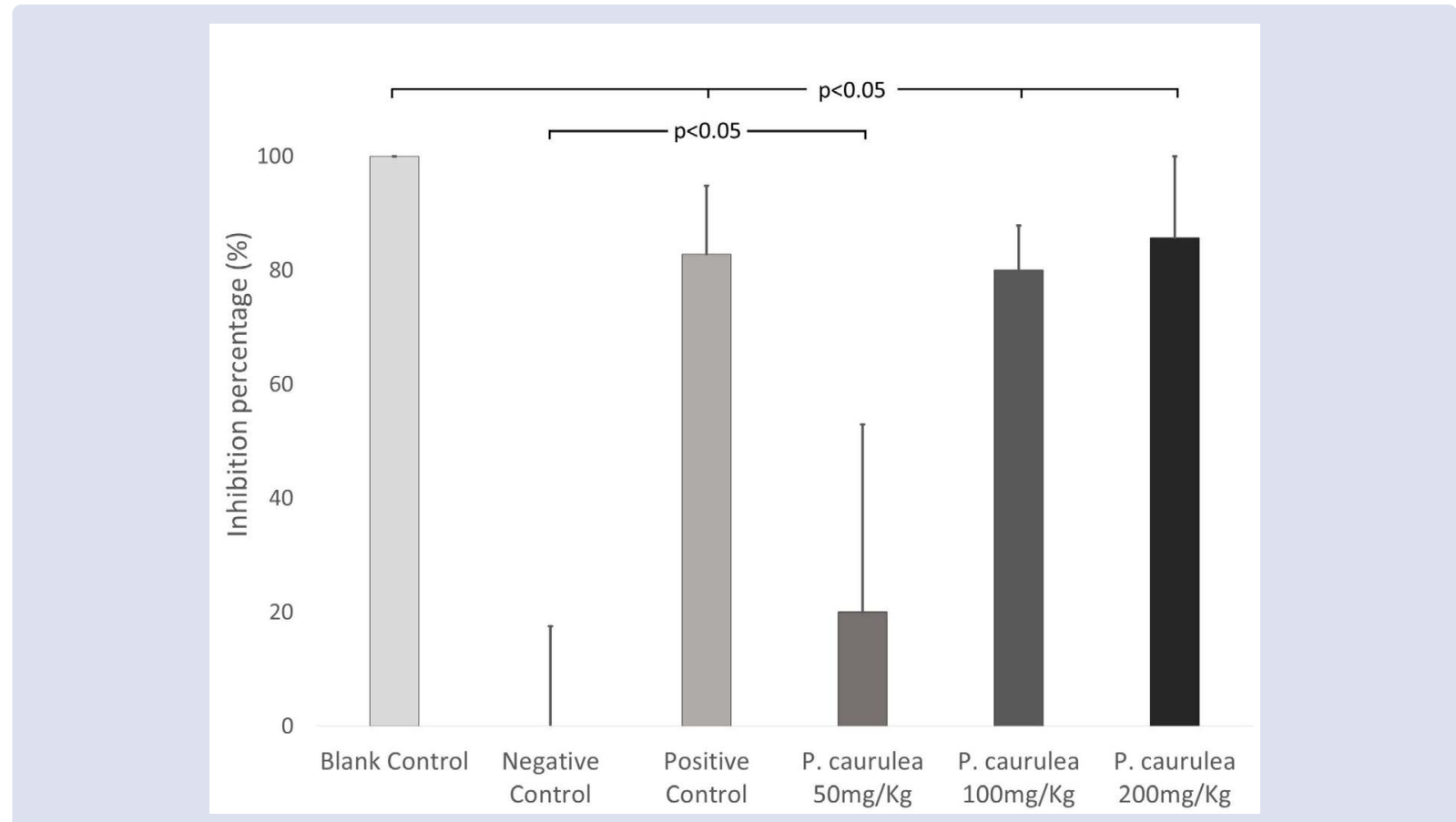

Figure 2: Gastric antiulcer effect of Persea caerulea extract (Ruiz \& Pav.) Mez expressed as a percentage of ulceration inhibition. $n=5, p<0.05$.

that acts as an important cellular defense against oxidative stress, leading to aggravated tissue damage during gastroduodenal ulceration. ${ }^{29}$ Free radicals initiate microvascular permeability, generating additional infiltration of plasma cells and macrophages into gastric endothelial cells, leading to inflammation. ${ }^{30}$

Polyphenols are one of the most abundant secondary metabolites, they are ubiquitously present in fruits and vegetables, and are considered an integral part of the human diet. Polyphenols consist of a wide variety of chemical structures based on substitutions of the basic chemical structure of polyphenols, polymerization, and degree of oxidation ${ }^{29}$. Polyphenols reported in P. caerulea, such as: quercetin, kaempferol-3O- $\alpha$-L-rhamnopyranoside, kaempferol-3-O- $\alpha$-L-arabinopyranoside, quercetin-3-O- $\alpha$-L-rhamnopyranoside, quercetin -3-O- $\beta$-glucoside, would give the extract of this plant the gastroprotective activity, which 
is related to the quantified in total polyphenols of the hydroalcoholic extract of $P$. caerulea expressed in $\mathrm{mg}$ of Gallic acid.

Quercetin has gastroprotective activity and is due to antioxidant activity that reduces lipoperoxidation. Research has shown that quercetin has an effective antiulcer activity, protects and prevents changes in biochemical and morphological parameters observed after induction of ulcer with ethanol in rats. ${ }^{31}$ Thiobarbituric acid reactive substances in the gastric mucosa, an index of lipoperoxidation, were increased by ethanol ulcer injury, but the increase was inhibited by quercetin administration. ${ }^{32} \mathrm{Also}$, a pharmaceutical preparation combining famotidine and quercetin was used to increase the treatment of gastric ulcer, this combined treatment showed absence of signs of inflammation or bleeding and significantly prevented the indomethacin-induced decrease in glutathione levels and decreased the levels of malondialdehyde. ${ }^{33}$ Quercetin has an antioxidant effect and can protect the gastric mucosa against indomethacin-induced gastric ulceration than famotidine. ${ }^{34}$

Kaempferol, like quercetin, is a common type of flavonoid with antioxidant and anti-inflammatory properties. ${ }^{35}$ Kaempferol can protect the stomach by inhibiting neutrophil accumulation and myeloperoxidase activity, regulating pro-inflammatory cytokine levels, and enhancing NO production to maintain gastric mucosal glycoprotein levels. ${ }^{36}$ Kaempferol reduces the expression of proinflammatory cytokines (TNF- $\alpha$, IL- $1 \beta$, and IL-8) and the production of IL-8 in H. pylori-infected gastric adenocarcinoma cells. ${ }^{37}$ In a model of gastric injury by ethanol, kaempferol significantly decreased the ulcer index, increased the preventive index, completely protected the mucosa from injury and conserved gastric mucosa glycoprotein, decreased myeloperoxidase activity and cytokine levels. proinflammatory. ${ }^{36}$

The extract of $P$. caerulea has an effect similar to ranitidine and it is postulated that this effect is mainly due to the action of compounds such as quercetin and kaempferol, polyphenols reported in P. caerulea that have antioxidant and anti-inflammatory activity. ${ }^{30,32,35}$

\section{CONCLUSION}

The hydroalcoholic extract of the bark of Persea caerulea (Ruiz \& Pav.) $\mathrm{Mez}$, at doses of 100 and $200 \mathrm{mg} / \mathrm{Kg}$, has a gastric antiulcer effect similar to that of ranitidine, and this activity is related to the content of polyphenols totals.

\section{CONFLICTS OF INTEREST}

Authors declare no conflicts of interest.

\section{AUTHOR CONTRIBUTIONS}

ACP and CSC carried out the preparation of the first draft and preparation of the extract. MSC and MLS performed gastric ulcer induction, MVA and FHC administered the treatments. WAD collected the plant species. LGE and OPS carried out the evaluation with the Marhuenda Scale and determination of percentages of ulceration inhibition. CAV and VVLT performed the quantification of total polyphenols. MGB and JHV performed the statistical analysis. AGS and WSG designed tables and figures.

\section{REFERENCES}

1. Bi W, Man H, Man M. Efficacy and safety of herbal medicines in treating gastric ulcer: a review. World J Gastroenterol. 2014;20(45):17020-17028.

2. Ford A, Gurusamy K, Delaney B, Forman D, Moayyedi P. Eradication therapy for peptic ulcer disease in Helicobacter pylori-positive people. Cochrane Database Syst Rev. 2004;4:1-15.

3. Sofowora A, Ogunbodede E, Onayade A. The role and place of medicinal plants in the strategies for disease prevention. Afr J Tradit Complement Altern Med. 2013;10(5):210-229.
4. Akinbo F, Eze G. Combined Effects of Medicinal Plants on Induced Upper Gastrointestinal Tract Injury in Wistar Rats. Ethiop J Health Sci. 2016;26(6):573-580

5. Tariq A, Mussarat S, Adnan M, Abd_Allah E, Hashem A, Alqarawi $A$, et al. Ethnomedicinal evaluation of medicinal plants used against gastrointestinal complaints. Biomed Res Int. 2015;2015:892947.

6. Ferrer-Pereira $\mathrm{H}$. Aportes al conocimiento taxonómico del género Persea (Lauraceae) en Venezuela. Hoehnea. 2012;39(3):435-478

7. Álvarez J, Raya-Barón A, Nieto P, Cuca L, Carrasco A, FernándezGutiérrez A, Fernández I. Flavonoid glycosides from Persea caerulea. unraveling their interactions with SDS-Micelles through matrix-assisted DOSY, PGSE, mass spectrometry and NOESY. Mang Reson Chem. 2016;54(9):718-728.

8. Alvárez J, Cuca L, Carrasco-Pancorbo A, Ruiz-Muelle A, Fernández I, Fernández-Gutiérrez A. Phenolic constituents of leaves from Persea caerulea Ruiz \& Pav; Mez (Lauraceae). Biochemical Systematics and Ecology. 2016;67:53-57.

9. Torres P, Aguilar J, Rodríguez A, Pretel O. Efecto de Mirabilis jalapa $L$. frente a radicales libres inducidos por Escherichia coli en Rattus rattus variedad albinus. Revista de Biología. 2007;10:53-58.

10. Rosas-Cruz GP, Silva-Correa CR, Calderón-Peña AA, VillarrealLa Torre VE, Aspajo-Villalaz CL, Cruzado-Razco JL, et al. Wound Healing Activity of an Ointment from Solanum tuberosum L. "Tumbay Yellow Potato" on Mus musculus Balb/c. Pharmacogn J. 2020;12(6):1268-1275

11. Pizarro A, Valido A, Santiesteban D, Valdés M, Mena Y, Evaluación de la actividad gastroprotectora de Matricaria recutita en ratas Sprague Dawley. REDVET. Revista Electrónica de Veterinaria. 2012;13(8):1-12.

12. Arroyo J, Bonilla P, Moreno-Exebio L, Ronceros G, Tomás G, Huamán J, et al. Efecto gastroprotector y antisecretor de un fitofármaco de hojas de matico (Piper aduncum). Rev Peru Med Exp Salud Publica. 2013; 30(4):608-615

13. Rollin B. Ethics and euthanasia. Can Vet J. 2009; 50(10):1081-1086.

14. Barrios E, Espinoza M, Leal U, Ruiz N, Pinto V, Jurado B. Bioética y el empleo de animales de experimentación en investigación. Salus. 2011;15(2):28-34.

15. Zatroch K, Knight C, Reimer J, Pang D. Refinement of intraperitoneal injection of sodium pentobarbital for euthanasia in laboratory rats (Rattus norvegicus). BMC Vet Res. 2017;13(60):1-7.

16. Huamán O, Sandoval M, Arnao I, Béjar E. Efecto antiulceroso del extracto hidroalcohólico liofilizado de hojas de Bixa orellana (achiote), en ratas. An. Fac. med. 2009;70(2): 97-102.

17. Hoshino T, Tsutsumi $S$, Tomisato $W$, Hwang H, Tsuchiya $T$, Mizushima T. Prostaglandin E2 protects gastric mucosal cells from apoptosis via EP2 and EP4 receptor activation. J Biol Chem. 2003;278(15):12752-12758.

18. Kakuta $H$, Zheng $X$, Oda $H$, Harada $S$, Sugimoto $Y$, Sasaki $K$, et al. Cyclooxygenase-1-selective inhibitors are attractive candidates for analgesics that do not cause gastric damage. Design and in vitro/ in vivo evaluation of a benzamide-type cyclooxygenase-1 selective inhibitor. Journal of Medicinal Chemistry. 2008;51(8):2400-2411.

19. Morham S, Langenbach $R$, Loftin $D$, Tiano $H$, Vouloumanos $N$, Jennette J, et al. Prostaglandin synthase 2 genes disruption causes severe renal pathology in the mouse. Cell. 1995; 83(3):473-482.

20. Zheng $X$, Oda $H$, Takamatsu $K$, Sugimoto $Y$, Tai $A$, Akaho E, et al. Analgesic agents without gastric damage: Design and synthesis of structurally simple benzenesulfonanilide-type cyclooxygenase1-selective inhibitors. Bioorganic \& Medicinal Chemistry. 2007;15(2):1014-1021.

21. Baumeister B, Schmidt C, Schiermeyer-Dunkhase B, Vetter $\mathrm{H}$, Kipnowski J. Decreased gastric prostaglandin E2 synthesis in patients with gastric ulcers and in smokers. HepatoGastroenterology. 1995;42(6):851-855. 
22. Pai R, Tarnawski A. Signal transduction cascades triggered by EGF receptor activation: Relevance to gastric injury repair and ulcer healing. Digestive Diseases and Sciences. 1998; 43(9): 14s-22s

23. Fang $Y, X u$ W, Wang L, Lian $Q$, Qiu L, Zhou H, et al. Effect of hydrotalcite on indometacin-induced gastric injury in rats. Biomed Res Int. 2019; 2019:1-10

24. Suemasu S, Tanaka K, Namba T, Ishihara T, Katsu T, Fujimoto M, et al. A role for HSP70 in protecting against indomethacin-induced gastric lesions. J Biol Chem 2009; 284(29):19705-19715.

25. Ou Y, Yang C, Cheng C, Raung S, Hung Y, Chen C. Indomethacin induces apoptosis in 786-O renal cell carcinoma cells by activating mitogen-activated protein kinases and AKT. Eur J Pharmacol. 2007; 563(1-3): 49-60.

26. Guillemot L, Citi S. Cingulin regulates claudin-2 expression and cell proliferation through the small GTPase RhoA. Mol Biol Cell 2006;17(8): 3569-77

27. Thakre-Nighot $M$, Blikslager A. Indomethacin induced increase in gastric epithelial tight junction permeability via redistribution of occludin and activation of p38 MAPK in MKN-28 Cells. Tissue Barriers. 2016; 4(3):1-12

28. Higuchi K, Watanabe T, Tominaga K, Shiba M, Nakagawa K, Uno $\mathrm{H}$, et al. Effects of ranitidine on quality of gastric ulcer healing compared with famotidine: a randomized, controlled, multicenter trial. Int J Clin Pharmacol Res. 2005; 25:187-194.

29. Farzaei M, Abdollahi M, Rahimi R. Role of dietary polyphenols in the management of peptic ulcer. World J Gastroenterol. 2015; 21(21): 6499-6517.
30. Tandon R, Khanna HD, Dorababu M, Goel R. Oxidative stress and antioxidants status in peptic ulcer and gastric carcinoma. Indian J Physiol Pharmacol. 2004;48:115-118.

31. Coşkun Ö, Kanter M, Armutçu F, Çetin K, Kaybolmaz B, Yazgan Ö Protective effects of quercetin, a flavonoid antioxidant, in absolute ethanol-induced acute gastric ulcer. Eur J Gen Med 2004;1(3):37-42

32. Martín M, La-Casa C, Alarcón-de-la-Lastra C, Cabeza J, Villegas I, Motilva $\mathrm{V}$. Anti-oxidant mechanisms involved in gastroprotective effects of quercetin. Z Naturforsch C J Biosci. 1998;53(1-2): 82-88.

33. Abourehab M, Khaled K, Sarhan H, Ahmed O. Evaluation of combined famotidine with quercetin for the treatment of peptic ulcer: in vivo animal study. Drug Des Devel Ther. 2015;9:2159 2169.

34. Alkushi A, Elsawy N. Quercetin attenuates, indomethacin-induced acute gastric ulcer in rats. Folia Morphol (Warsz). 2017;76(2):252 261.

35. Ren J, Lu Y, Qian Y, Chen B, Wu T, Ji G. Recent progress regarding kaempferol for the treatment of various diseases. Exp Ther Med. 2019;18(4):2759-2776.

36. Li Q, Hu X, Xuan Y, Ying J, Fei Y, Rong J, Zhang Y, Zhang J, Liu C, Liu Z. Kaempferol protects ethanol-induced gastric ulcers in mice via pro-inflammatory cytokines and NO. Acta Biochim Biophys Sin (Shanghai). 2018;50:246-253

37. Yeon $M$, Lee $M$, Kim D, Yang J, Woo $H$, Jin $H$, et al. Antiinflammatory effects of Kaempferol on Helicobacter pylori-induced inflammation. Biosci Biotechnol Biochem. 2019:83(1):166-173.

\section{GRAPHICAL ABSTRACT}
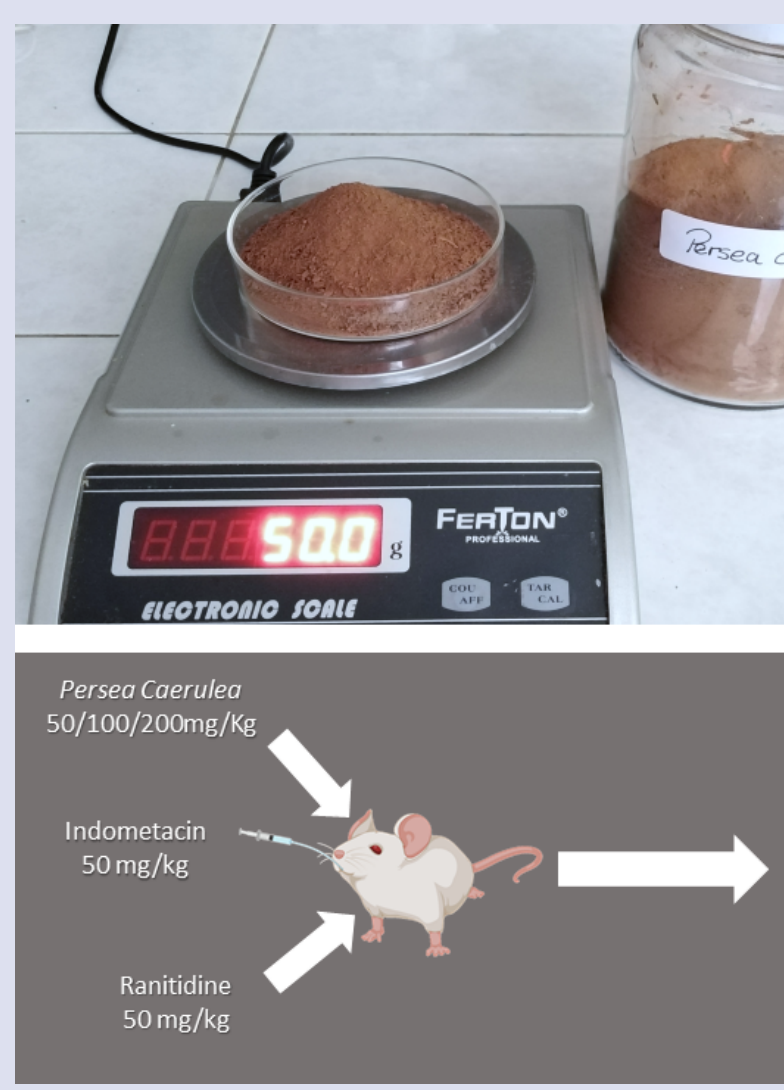
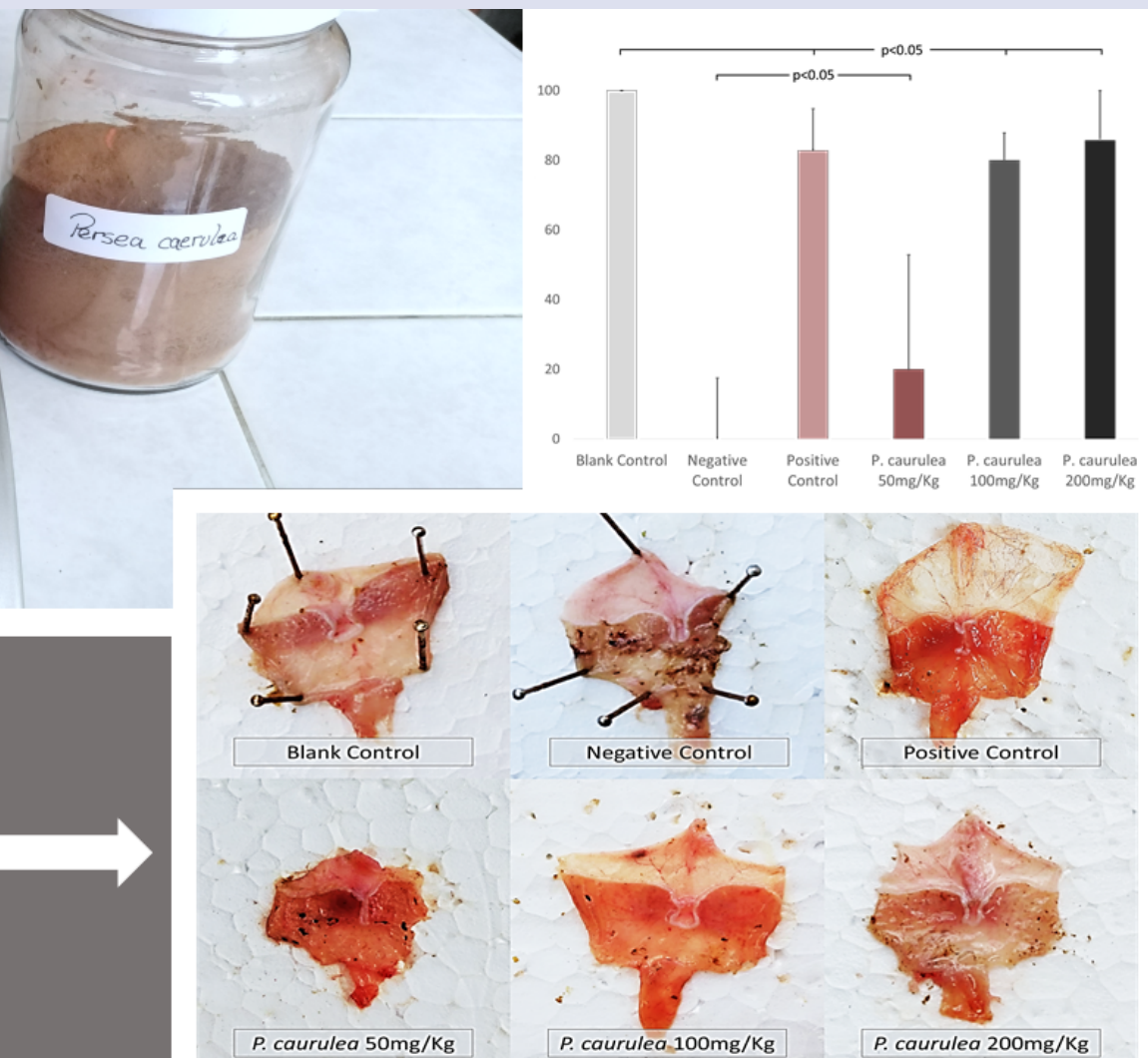


\section{ABOUT AUTHORS}

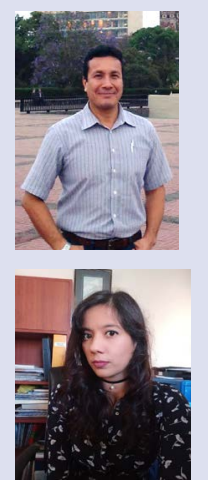

Calderón-Peña Abhel A. Doctor in Biological Sciences. Master of Physiology and Biophysic, holds a degree in Biological Science from Universidad Nacional de Trujillo. Animal Physiology, Human Anatomy, Histology and Biochemistry Professor of undergraduate program at the Universidad Nacional de Trujillo. $\mathrm{He}$ is currently conducting research on oxidative stress and the discovery of antioxidant compounds in medicinal plants.

Aspajo-Villalaz Cinthya L. Master of Food Technology holds a degree in Biological Science from Universidad Nacional de Trujillo. Bromatology and Biochemistry Professor of undergraduate program at the Universidad Nacional de Trujillo. She is currently conducting research on microbiological control of pharmaceutical products, functional foods design and evaluation. Graduate student at Doctoral in the Biological Sciences program.

Silva-Correa Carmen R. Department of Pharmacology professor at Universidad Nacional de Trujillo, holds a degree in Pharmacy and Biochemistry (2011), Master of Chemical Sciences (2017), graduate student at Doctoral program in Biomedical Sciences since 2019. Currently participates in research projects on toxicological and pharmacological evaluation of medicinal plants, focusing in the evaluation of the wound healing activity of traditional medicinal plants from Peru

Villarreal-La Torre Víctor E. Master of Chemical Sciences, holds a degree in Pharmacy from Universidad Nacional de Trujillo (2011). Professor in the Medicinal Chemistry undergraduate program and the Molecular basis of the Action of Xenobiotics postgraduate program at the Universidad Nacional de Trujillo. He currently executes research projects aimed at the discovery of antimicrobial compounds in medicinal plants. Graduate student at Doctoral program in Pharmacy and Biochemistry since 2019.

González-Blas María V. Master of Chemical Sciences holds a degree in Pharmacy and Biochemistry from Universidad Nacional de Trujillo, Doctorate studies in Biomedical Sciences. She has participated in research projects of hypoglycemic, diuretic and antileishmanicidal activity of compounds in medicinal plants.

Pretel-Sevillano Orlando E. Doctor in Biomedical Science, Master of Physiology, holds a degree in Biological Science from Universidad Nacional de Trujillo. Undergraduate professor in Animal Physiology, Human Anatomy, Biochemistry and Human and Animal Nutrition; thesis advisor in undergraduate and graduate studies. He currently conducts research on medicinal plants in hormonal regulation in health and disease.

Salazar-Castillo Marco L. Doctor in Biological Sciences. Master of Science in Biochemistry mention. Microbiologist Biologist, Environmental Engineer. Principal Professor of the Department of Biological Chemistry and Animal Physiology, School of Biological Sciences of the Universidad Nacional de Trujillo-Peru, where he teaches courses on Biochemistry, Bromatology, Nutrition and Natural Products and Phytochemistry. Line of Research: Enzymology and Enzyme Technology, Natural Products and Entomopathogens.

Vaella-Alarcón Maricielo Jocelyn. Biological Sciences undergrad student at Universidad Nacional de Trujillo, with complimentary education in biochemistry at Granada University and genetics and biotechnology at Universidad Nacional Mayor de San Marcos. Has made research in the Animal Physiology laboratory of the Faculty of Biological Sciences of the Universidad Nacional de Trujillo, looking for new compounds with pharmaceutical use in foreign plants such as protection against oxidative stress and ulcers healing and prevention. Currently focused on drug design.

Huaccha-Cáceres Franco Javier. Undergraduate student in Biological Sciences at the Universidad Nacional de Trujillo (UNT) and the Autonomous Metropolitan University. Member and part of National Relations in the Peruvian Society of Bioinformatics, Journal Club UNT and Regional Student Groups (RSG) of Peru of the SCISCB. He has developed research in the Animal Physiology laboratory of the Faculty of Biological Sciences of the Universidad Nacional de Trujillo. He is currently investigating the pharmacological action of compounds from native peruvian medicinal plants in murine models. 


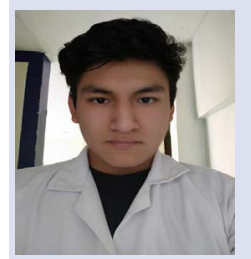

Jonatam Miguel Leon-Soto. Undergraduate student in Biological Sciences at the Universidad Nacional de Trujillo. He has participated in the XVIII National Congress of Biology Students - CONEBIOL as a scientific speaker. He has developed research in the Animal Physiology laboratory of the Faculty of Biological Sciences of the Universidad Nacional de Trujillo. He is currently investigating the pharmacological action of natural products.

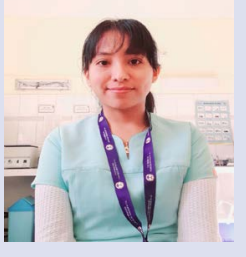

Alaya-Daviran Whendy Patricia. She is biologist graduated from the Faculty of Biological Sciences of the Universidad Nacional de Trujillo. She developed research in the Animal Physiology laboratory of the Faculty of Biological Sciences. She currently works in the area of clinical and biological analysis Ministry of Health (MINSA). She oriented to clinical research.

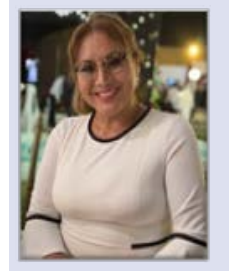

González-Siccha Anabel D. Doctor in Pharmacy and Biochemistry. Master of science in Biochemistry. Magister in Physiology. Pharmacy degree in Spain. Second degree in Clinical and Biological Analysis. Principal Professor of Biochemistry and Molecular Biology undergraduate program of the Department of Biochemistry, Pharmacy and Biochemistry Faculty at the Universidad Nacional de Trujillo. Research Fellow in the Laboratory of Biochemistry and Molecular Biology at the Faculty of Medicine from Albacete, Universidad de Castilla-La Mancha from Spain. Research on Nutritional assessment and anemia in vulnerable populations. Research on medicinal plants on immunomodulatory, antitumor and tumor marker activity. Research on DLK1 and DLK2 proteins and differentiation on mouse tissues through immunohistochemistry.

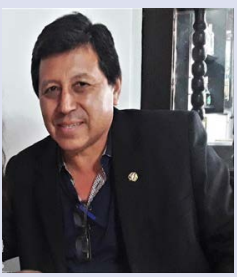

Sagástegui-Guarniz William Antonio. Department of Pharmacology professor at Universidad Nacional de Trujillo, Perú since 1993 - to date. I am a graduated in Pharmacy and Biochemistry. Speaker at the graduate program of Universidad Nacional de Trujillo. Has bachelor in pharmaceutical chemistry 1988. Master's in chemical sciences, 1999. Doctorate in Biomedical Sciences, graduate program of the Universidad Nacional de Trujillo, 2010. Doctorate studies at Universidade Federal Do Ceará, Brazil, 2015-2018. Currently participates in research projects aimed at the phytochemical characterization of medicinal plants, focusing on antimicrobial activity, resistance to antimicrobials, and antimalarial.

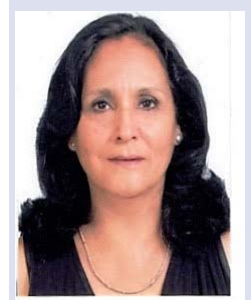

Guerrero-Espino Luz M. Professor. Department of Physiology. School of Medicine - Universidad Nacional de Trujillo, PhD in Biomedical Sciences, Master's Degree in Physiology. Researcher in neuroscience, altitude and exercise.

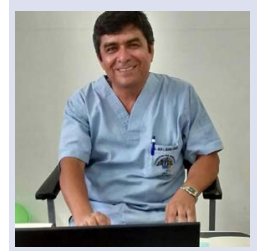

Hilario-Vargas, Julio S. Professor. Departamento de Fisiología, Facultad de Medicina. Universidad Nacional de Trujillo. Master in Physiology and Doctor in Biomedical Science. Research and publishes works on pemphigus, evaluation of medicinal plant extracts, and physiological function in special environments.

Cite this article: Calderón-Peña AA, Aspajo-Villalaz CL, Silva-Correa CR, Villarreal-La Torre VE, González-Blas MV, Pretel-Sevillano OE, et al. Total Phenol Content and Gastric Anti-Ulcer Activity of Hydroalcoholic Extract of Persea caerulea (Ruiz \& Pav.) Mez. Bark. Pharmacogn J. 2021;13(5): 1072-1078. 